\title{
PENERAPAN BERBAGI KEUNTUNGAN DAN KERUGIAN DALAM PEMBIAYAAN MURABAHAH DI BANK SYARIAH INDONESIA
}

\author{
Ahmad Supriyadi \\ Dosen STAIN Kudus \\ supriyadi515@yahoo.com
}

\begin{abstract}
The research on profit and loss in the transactions of Islamic banks aims to explore the application of the law and find the factors of application of the law of sharing profit and loss in murabahah financing in Bank Syariah Indonesia that has not provided justice. Is a qualitative empirical law research with problem solving approach through case approach, normative, juridical and the type of research is field research or field research, then do also observation and analysis with inductive method so that problem formulated can be resolved. The result of this research is the application of law about share of profit and loss in murabahah financing in Bank Syariah Indonesia has not give justice factor is three things that is weakness from side of law substance, legal structure and law culture.
\end{abstract}

\begin{abstract}
Abstrak
Penelitian mengenai bagi untung dan rugi didalam transaksi bank syariah ini bertujuan untuk menggali penerapan hukumnya dan menemukan faktor-faktor penerapan hukum berbagi keuntungan dan kerugian dalam pembiayaan murabahah di Bank Syariah Indonesia yang belum memberikan keadilan. merupakan penelitian hukum empiris kualitatif dengan penyelesaian rumusan masalah melalui pendekatan kasus, normatif, yuridis dan jenis penelitiannya adalah penelitian lapangan atau field research, kemudian dilakukan juga observasi dan analisa dengan metode induktif sehingga masalah yang dirumuskan dapat terselesaikan. Hasil dari penelitian ini adalah penerapan hukum tentang berbagi keuntungan dan kerugian dalam pembiayaan murabahah di Bank Syariah Indonesia belum memberikan keadilan faktornya adalah tiga hal yaitu kelemahan dari sisi substansi hukum, struktur hukum dan kultur hukum.
\end{abstract}

\section{A. Pendahuluan.}

Bank Syariah adalah badan usaha yang bergerak di bidang jasa keuangan yang kegiatannya adalah menghimpun dana dan menyalurkannya kepada masyarakat serta kegiatan ekonomi lainnya berupa jasa dan dapat menerima zakat, infaq dan sadaqah serta menyalurkannya kepada yang berhak. Bank Syariah merupakan lembaga yang ideal baik secara filosofis, yuridis dan sosiologis. ${ }^{1}$ Secara filosofis Bank Syariah merupakan

\footnotetext{
Mustaghfirin, 2006, Rekonstruksi Sistem Hukum Perbankan di Indonesia Kajian dari Aspek Filososfis, Sosiologis dan Budaya, Unissula Press, Semarang, hal. 9-16. Dan Dadan Muttaqien, 2007, Sistem Perbankan Syariah di Indonesia dalam Perspektif Politik Hukum, Disertasi Universitas Diponegoro, Semarang, hal.361.
}

lembaga keuangan yang sesuai dengan ideologi bangsa Indonesia yaitu Pancasila mulai dari sila pertama hingga sila ke lima dan pembukaan Undang-Undang Dasar 1945. ${ }^{2}$ Lebih kuat lagi secara filosofis sesuai dengan al-Qur'an dan Hadis.

Bank Syariah secara yuridis sesuai dengan perundang-undangan yang ada di Indonesia yaitu Undang-Undang Nomor 7 Tahun 1992 tentang Perbankan yang dibarengi dengan lahirnya Peraturan Pemerintah Nomor 72 Tahun 1992 tentang Bank Berdasarkan Prinsip Bagi Hasil. Kemudian undang-undang tersebut diubah dengan Undang-Undang Nomor 10 tahun 1998 tentang perbankan, kemudian diatur dengan perundang-

2 Op.Cit. Mustagfirin, hal. 9-16 dan Dadan Muttaqien, hal.361 
undangan sendiri yaitu Undang-Undang Nomor 21 Tahun 2008 tentang Perbankan Syariah. Selain perundang-undangan, perbankan syariah diatur juga dalam Peraturan Bank Indonesia, kompilasi hukum ekonomi syariah dan fatwa Dewan Syariah Nasional.

Secara sosiologis Bank Syariah juga sesuai dengan kebutuhan masyarakat Indonesia. Pertama, mayoritas penduduk Indonesia adalah muslim yang membutuhkan bank yang sesuai dengan prinsip Islam yaitu berbagi keuntungan dan kerugian, kedua praktik perbankan syariah bagi hasil sudah merupakan bagian dari budaya masyarakat Indonesia yang dalam berbagai kegiatan ekonomi menerapkan "“maro, mertelu". ${ }^{3}$ Maka menurut Dadan Muttaqien perbankan syariah sudah menjadi sine quanon keberadaannya di Indonesia, karena sesuai dengan budaya bangsa dan kegiatan usaha yang dijalankan oleh bangsa Indonesia.

Dalam penelitian ini penulis dapat menemukan penerapan hukum tentang berbagi keuntungan dan kerugian dalam pembiayaan murabahah di Bank Syariah Indonesia berdasarkan keadilan perspektif Hukum Islam. Selain itu, penulis juga menemukan faktor-faktor penerapan hukum berbagi keuntungan dan kerugian dalam pembiayaan murabahah di Bank Syariah Indonesia yang belum memberikan keadilan.

Penelitian ini merupakan penelitian hukum empiris kualitatif dengan penyelesaian rumusan masalah melalui pendekatan kasus, normatif, yuridis, sosiologis dan jenis penelitiannya adalah penelitian lapangan atau field research dimana data primer dikumpulkan dengan metode wawancara kepada nasabah, dan juga membaca buku-buku yang ditulis oleh para ahli tentang bank syariah, dilakukan juga observasi kemudian hasil penelitian dianalisis dengan metode induktif dengan cara reduksi data, penyajian data dan verifikasi data sehingga masalah yang dirumuskan dapat terselesaikan.

3 Dadan Muttaqien, 2007, Sistem Perbankan Syariah di Indonesia dalam Perspektif Politik Hukum, Disertasi Universitas Diponegoro, Semarang, hal.361

\section{B. Pembahasan}

1. Penerapan Hukum Tentang Berbagi Keuntungan dan Kerugian dalam Pembiayaan Murabahah di Bank Syariah Indonesia Ditinjau Berdasarkan Keadilan Perspektif Hukum Islam.

Hukum dapat diteliti dari dua sisi yaitu sisi law in book atau dalam peraturan perundang-undangan dan juga dapat diteliti dari sisi penerapannya atau law in action, di bab tiga ini peneliti mengkaji dari sisi penerapannya secara natural dan komprehensif tentang penerapan hukum pembiayaan murabahah dilihat dari sisi nilai keadilan berbagi keuntungan dan kerugian.

Peneliti mendiskripsikan penerapan hukum tentang pembiayaan murabahah di Bank Syariah Indonesia dari sisi berbagi keuntungan dan kerugian yang adil sesuai data yang ditemukan, baik primer yang diperoleh dengan wawancara kepada nasabah, maupun data sekunder yang diperoleh dari dokumen akta perjanjian pembiayaan murabahah dari Bank Syariah yang telah ditandatangani oleh nasabah dan Bank Syariah dihadapan notaris dan juga perjanjian di bawah tangan. Data yang diperoleh kemudian dianalisis menggunakan teori pembiyaan berbagi keuntungan dan kerugian yang adil.

Pembiayaan yang adil menurut teori pembiayaan adalah pembiayaan yang berbagi keuntungan dan kerugian artinya dalam pembiayaan itu ada keuntungan dan ada juga berbagi risiko kerugian. Kerugian pada umumnya berkaitan dengan risiko, maka pembiayaan dikatakan adil bila ada pembagian risiko antara bank dengan nasabah. Keuntungan pada umumnya berkaitan dengan materi yang diperoleh itu sah menurut syariah, maka keuntungan materi yang diperoleh Bank Syariah dan juga nasabah harus memenuhi kriteria yang sah menurut syariah. Kriteria keuntungan yang sah menurut syariah adalah pengambilan keuntungan yang dilakukan karena ada usaha dan tidak ada riba, tidak ada rekayasa akad atau gharar, dan tidak mengandung unsur judi, serta memberikan maslahah bagi bank dan nasabah. Menurut nilai-nilai di dalam 
Hukum Islam, mengambil keuntungan itu diperbolehkan bila memenuhi tiga kriteria yaitu : (1) adanya usaha yang dijalankan (2) adanya tanggungjawab terhadap usaha yang dijalankan dan (3) adanya tanggung jawab risiko.

Peneliti mencantumkan demikian tidaklah berlebihan karena hal itu sudah ada di dalam Undang-Undang Nomor 21 Tahun 2008 tentang perbankan syariah yaitu dalam landasan filosofi yaitu:

Dengan prinsip bagi hasil, Bank Syariah dapat menciptakan iklim investasi yang sehat dan adil karena semua pihak dapat saling berbagi baik keuntungan maupun potensi risiko yang timbul sehingga akan menciptakan posisi yang berimbang antara bank dengan nasabahnya. ${ }^{4}$

Kalimat yang menjadi penekanan di atas adalah "semua pihak dapat saling berbagi baik keuntungan maupun potensi risiko yang timbul sehingga akan menciptakan posisi yang berimbang antara bank dengan nasabahnya". Kalimat tersebutlah yang menunjukkan keadilan adalah berbagi keuntungan dan keadilan. Hal itu juga seirama dengan pendapat para ahli perbankan syariah bahwa ruh Bank Syariah adalah bank berbagi keuntungan dan kerugian.

Atas dasar filosofi tersebut Pasal 3 Undang-Undang Nomor 21 Tahun 2008 tentang perbankan syariah juga menekankan adanya keadilan di dalam tujuan perbankan syariah yaitu Perbankan Syariah bertujuan menunjang pelaksanaan pembangunan nasional dalam rangka meningkatkan keadilan, kebersamaan, dan pemerataan kesejahteraan rakyat". Pasal tersebut memberikan ruh tujuan perbankan syariah yaitu keadilan, kebersamaan dan pemerataan kesejahteraan yang bila disimpulkan adalah berbagi keuntungan dan kerugian. Teori tersebut menjadi landasan untuk mengukur penerapan hukum tentang berbagi keuntungan dan kerugian dalam pembiayaan murabahah

4 Tim Redaksi Fokus Media, 2008, Himpunan Peraturan Perundang-Undangan Tentang UndangUndang Perbankan Syariah dan Surat Berharga Syariah Negara, Penerbit Fokus Media, Bandung, hal.83 di Bank Syariah itu adil atau tidak menurut Hukum Islam.

Peneliti perlu memberikan standar yang jelas sebagaimana tersebut, dengan tujuan agar pemaknaan data-data dalam bab tiga ini dalam persepsi yang utuh dan sama, sehingga tidak menimbulkan perbedaan dalam pandangan. Ada persepsi yang salah di kalangan sebagian praktisi perbankan syariah menurut peneliti dan juga sebagian ahli perbankan syariah, yaitu bahwa dalam jual beli murabahah itu tidak perlu ada berbagi keuntungan dan kerugian karena di dalam hal jual beli dengan prinsip murabahah yang ada adalah penjual, pembeli, barang dan juga uang serta sighat jual beli. ${ }^{5}$ Kekeliruan terletak pada persepsi bahwa persyaratan yang disebutkan adalah jual beli secara umum, sementara praktik pembiayaan di Bank Syariah tidak hanya berlaku persyaratan umum tetapi juga persyaratan khusus yaitu adanya hubungan kerjasama antara penjual dan pembeli dengan berbagi keuntungan dan kerugian. Bila ruh berbagi keuntungan dan kerugian di Bank Syariah itu hilang, maka sejatinya Bank Syariah akan sama dengan bank konvensional yaitu sebagai bank murabahah yang sama dengan bank konvensional dengan berbasis riba, hanya terletak pada sebutan nomenklatur saja yang berubah.

Pembiayaan murabahah di Bank Syariah diukur dari nilai-nilai Hukum Islam dari Abul A'la al-Maududi 6 yang dikuatkan oleh Mannan ${ }^{7}$ dan juga Ascarya tidak memenuhi tiga unsur yaitu: Pertama, pengambilan keuntungan didasarkan pada adanya usaha yang dijalankan. Kedua, adanya tanggungjawab atas bisnis yang ia jalankan sebagaimana dalam kaedah

5 Wawancara dengan $\mathrm{H}$. Hamdani ketua MUI Kabupaten Kudus tanggal 10 Januari 2017 "dalam murabahah yang ada dalah keuntungan di pihak penjual saja dan kerugian juga ada di pihak penjual saja".

6 Abul A'la al-Maududi, Riba, 1970, Terjemahan Abdullah Suhaili, Penerbit Hudaya, Jakarta, hal.23

Muhammad Abdul Mannan, 1995, Islamic Economics, Theory and Practice, terjemahan M. Nastangin, Teori dan Praktik Ekonomi Islam, Penerbit Dana Bhakti Wakaf, Yogyakarta, hal.205. 
ushul fiqh disebutkan "keuntungan menyertai tanggungjawab dan atas kerugian (al-kharaj bi al-daman). ${ }^{8}$ Ketiga, adanya berbagi risiko yang ditanggung. Beberapa ketidakadilan dalam pembiayaan murabahah adalah:

1) Nasabah menanggung risiko secara totalitas mulai dari pembelian barang hingga barang itu ada pada nasabah sedangkan Bank Syariah tidak mau menanggung risiko.

2) Bank Syariah mengambil keuntungan yang tidak sesuai syariah yaitu pengambilan keuntungan dalam syariah diperbolehkan asalkan ada usaha yang dijalankan, ada pembagian tanggung jawab dan pengusaha siap menanggung risiko.

3) Nasabah dibebani biaya-biaya administrasi, notaris sampai biaya asuransi yang semestinya biaya itu adalah tanggung jawab bersama kalau berbagi keuntungan dan kerugian.

4) Adanya rekayasa akad yaitu dalam perjanjian disebutkan jual beli barang, tetapi kenyataannya adalah utang uang yang harus dikembalikan oleh nasabah dengan menambah bunga yang dikehendakioleh BankSyariah.

5) Model pengembalian utang yang tidak adil yaitu seperti model bunga menurun sehingga kalau nasabah akan melunasi lebih awal, nasabah akan terbebani pokok yang masih banyak dan tidak semestinya, yang bila dibandingkan dengan pengembalian utang model flat baik pokok dan bunganya, kemudian nasabah terbebani membayar pinalti bunga satu kali angsuran.

6) Jual Beli Murabahah Rasa Pinjam Meminjam Uang. Bank Syariah sejatinya adalah pinjam meminjam uang yang dibungkus dengan akad

Frank E. Vogel dan Samuel L. Hayes, 1998, Islamic Law And Finance: Religion, Risk, And Return, Kluwer Law International, Cambridge, Massachusetts, Terjemahan, M. Sobirin Asnawi, Siwi Purwandari dan Waluyati Handayani, 2007, Hukum Keuangan Islam: Konsep, Teori dan Praktik, Penerbit Nusamedia, Bandung, hal.138 jual beli murabahah.

7) Bank syariah tidak melakukan usaha yang riil tetapi sebagai perantara. Bank Syariah hanyalah perantara antara investor dengan dunia usaha sehingga ia tidak melakukan usaha yang riil.

8) Bank syariah tidak berbagi risiko, hal ini ditunjukkan dengan didalam janjikan dalam akad bahwa nasabah bertanggung jawab atas barang yang dibeli sendiri oleh nasabah termasuk dokumen-dokumennya atau surat bukti kepemilikan barang dan Bank Syariah melepaskan diri untuk bertanggung jawab terhadap risiko barang, padahal seharusnya banklah yang membeli dan bank juga yang bertanggung jawab atas risiko.

9) Pengambilan keuntungan pembiayaan murabahah di Bank Syariah berdasarkan besarnya pinjaman, lamanya waktu pembiayaan dan suku bunga Bank Indonesia. Bila membandingkan antara kredit di bank konvensional dengan pembiyaan murabahah di Bank Syariah akan tampak bahwa bank konvensional mengambil keuntungan pada kredit didasarkan pada besarnya pinjaman, lamanya waktu pembiayaan, inflasi dan suku bunga Bank Indonesia, begitu juga Bank Syariah dalam pengambilan keuntungan pembiayaan murabahah.

10) Bank Syariah mewakilkan nasabah untuk pembelian barang tanpa adanya imbalan. Praktik pembiayaan murabahah di bank syariah dalam hal pembelian barang selalu diwakilkan kepada nasabah, sehingga bank meminta nasabahlah yang bertanggung jawab terhadap risiko bila ada, namun dalam pelaksanaan pembelian barang, nasabah tidak pernah mendapatkan imbalan berupa uang. 
2. Faktor Penerapan Hukum yang Belum Adil Tentang Berbagi Keuntungan dan Kerugian dalam Pembiayaan Murabahah di Bank Syariah Indonesia.

Faktor yang menyebabkan ketidakadilan dalam penerapan berbagi keuntungan dan kerugian pada pembiayaan murabahah yaitu faktor substansi hukum, faktor struktur hukum dan faktor kultur hukum. pertama, faktor substansi hukum yaitu (1) adanya dua regulasi yang kontradiksi yaitu undang-undang tentang perbankan konvensional berbasis bunga yang tidak adil dengan undang-undang tentang perbankan syariah berbasis berbagi keuntungan dan kerugian yang adil, (2) isi materi undang-undang tentang perbankan syariah yang belum mengatur di dalam pasal-pasalnya tentang murabahah yang berbagi keuntungan dan kerugian, (3) fatwa MUI dan Peraturan Bank Indonesia yang mengatur tentang pembiayaan murabahah sebagai regulasi yang lemah dalam hierarkhi perundang-undangan.

Kedua faktor ketidakadilan dalam pelaksanaan berbagi keuntungan dan kerugian juga ada dalam struktur hukum antara lain: (1) adanya dualisme lembaga perbankan yang kontradiksi yaitu perbankan konvensional dan perbankan syariah, (2) bank syariah lebih menerapkan keadilan formalitas dari pada keadilan substansial dalam pembiayaan murabahah, (3) bank syariah masih berparadigma kapitalis dan belum berparadigma islami dalam pembiayaan murabahah, (4) bank syariah bertujuan menghindari riba daripada menghilangkan riba dalam pembiayaan murabahah, (5) bank syariah tidak mau menerapkan berbagi kerugian dalam pembiayaan murabahah tetapi maunya untung terus, (6) bank syariah menerapkan hukum pembiayaan murabahah yang pragmatis sehingga kurang mengedepankan keadilan, (7) faktor persaingan antara bank syariah dan bank konvensional, (8) faktor kebijakan komisaris atau pemilik saham di bank syariah yang tidak sesuai dengan prinsip syariah yakni tidak mau menanggung kerugian, (9) faktor dewan pengawas syariah yang lemah dalam mengawasi pembiayaan murabahah di bank syariah.

Ketiga faktor yang menyebabkan ketidakadilan dalam pembiayaan murabahah adalah terkait dengan kultur hukum atau budaya hukum yang mencakup pengetahuan hukum, penghayatan hukum, penerapan hukum dan ketaatan hukum antara lain : (1) faktor lemahnya sebagian pakar perbankan tentang riba, (2) faktor sebagian nasabah atau masyarakat yang berparadigma pragmatisme kapitalisme, (3) faktor lemahnya pengetahuan masyarakat terhadap produk bank syariah, (4) faktor nilai mata uang yang selalu inflasi dan belum dijamin dengan emas yang stabil.

Ketiga faktor yang menyebabkan ketidakadilan dalam penerapan berbagi keuntungan dan kerugian pada pembiayaan murabahah yaitu faktor substansi hukum, faktor struktur hukum dan faktor kultur hukum tersebut dijabarkan sebagai berikut:

\section{a) Faktor Substansi Hukum}

Menurut Friedman bahwa substansi hukum merupakan bagian dari sistem hukum. Substansi hukum yang adil akan dapat melahirkan pelaksanaan hukum yang adil juga, dan sebaliknya substansi hukum yang tidak adil akan melahirkan pelaksanaan hukum yang tidak adil juga. Terkait dengan substansi hukum dalam pembiayaan murabahah di bank syariah adalah perundang-undangan yang mengatur tentang murabahah, peraturan Bank Indonesia tentang murabahah dan fatwa MUI tentang murabahah.

Faktor-faktor yang termasuk substansi hukum dalam pelaksanaan pembiayaan murabahah di Bank Syariah yang tidak adil adalah adanya dua regulasi perbankan yang kontradiksi $100 \%$ yaitu undangundang tentang perbankan konvensional berbasis bunga yang tidak adil dengan undang-undang tentang perbankan syariah berbasis berbagi keuntungan dan kerugian yang adil.

Di Indonesia lembaga perbankan ada dua yaitu perbankan konvensional dengan sistem bunga dan perbankan syariah dengan sistem berbagi keuntungan dan 
kerugian. Kedua lembaga tersebut juga diatur dengan dua perundang-undangan yaitu perbankan konvensional diatur dengan Undang-Undang Nomor 7 tahun 1992 jo. Undang-Undang Nomor 10 tahun 1998 tentang perbankan, sedangkan perbankan syariah diatur dengan UndangUndang Nomor 21 tahun 2008 tentang perbankan syariah. kedua undang-undang tersebut bagai air dan api yang bertolak belakang.

Bank Syariah dikatakan adil karena dalam pembiayaan yang diterapkan adalah prinsip bagi hasil. Maksud bagi hasil adalah berbagi keuntungan dan juga berbagi kerugian. Pelaksanaan atas undang-undang tersebut, diaturlah murabahah melalui pasal 19 ayat 1 huruf (d) yaitu kegiatan usaha Bank Umum Syariah meliputi: menyalurkan pembiayaan berdasarkan akad murabahah, akad salam, akad istishna', atau akad lain yang tidak bertentangan dengan prinsip syariah. $^{9}$

Berdasarkan pemaparan tersebut menunjukkan adanya substansi hukum yang kontradiksi antara perundangundangan yang mengatur perbankan syariah dengan perundang-undangan yang mengatur bank konvensional sehingga adanya duel system banking yang sangat bertentangan, di satu sisi perbankan konvensional diperbolehkan melakukan transaksi dengan prinsip bunga yang tidak adil, tetapi di sisi yang lain, Bank Syariah harus menerapkan prinsip berbagi keuntungan dan kerugian yang adil.

Undang-Undang Nomor 7 Tahun 1992 tentang Perbankan (Lembaga Negara Republik Indonesia Tahun 1992 Nomor 31, Tambahan Lembaran Negara Republik Indonesia Nomor 3472) sebagaimana telah diubah dengan Undang-Undang Nomor 10 Tahun 1998 (Lembaga Negara Republik Indonesia Tahun 1998 Nomor 182, Tambahan Lembaran Negara

UU Nomor 21 Tahun 2008 Tentang Perbankan Syariah
Republik Indonesia Nomor 3790) beserta peraturan pelaksanaannya, tidak berlaku dalam hal-hal yang bertentangan dengan Undang-Undang Nomor 21 Tahun 2008 bagi lembaga bank dan tidak terkecuali. Tetapi pada kenyataan, bank konvensional masih menerapkan bunga yang berdasarkan Undang-Undang Nomor 7 Tahun 1992 tentang Perbankan (Lembaga Negara Republik Indonesia Tahun 1992 Nomor 31, Tambahan Lembaran Negara Republik Indonesia Nomor 3472) sebagaimana telah diubah dengan Undang-Undang Nomor 10 Tahun 1998 (Lembaga Negara Republik Indonesia Tahun 1998 Nomor 182, Tambahan Lembaran Negara Republik Indonesia Nomor 3790) beserta peraturan pelaksanaannya.

Berdasarkan uraian tersebut ada kontradiksi yang signifikan yaitu antara perbankan berbasis bunga dengan perbankan berbasis syariah. Makna kontradiksi ini bukan berarti menyarankan Bank Syariah untuk menjalankan dengan sistem bunga, tetapi tampaknya hukum perbankan sudah mengalami kebingungan untuk menerapkan nilai keadilan yang harus diterapkan dalam hukum perbankan.

Kebingunan itu telah bercampur aduk antara prinsip bunga dengan prinsip syariah. Dalam kontek hukum, undangundang perbankan dapat dimaknai bahwa ia mengatakan pada bank konvensional "Berbuatlah kedzaliman kamu kepada para nasabah yang engkau layani" namun di sisi yang lain undang-undang mengatakan kepada Bank Syariah "Berbuatlah kamu dengan adil kepada para nasabah yang bertransaksi kepadamu". Karena itu pembangunan hukum perbankan di Indonesia menimbulkan ketidakpastian hukum

Kedua perundang-undangan tersebut sangat bertolakbelakang yaitu undangundang yang mengatur bank konvensional dengan berbasis bunga sedangkan undang-undang yang mengatur perbankan syariah dengan berbasis berbagi 
keuntungan dan kerugian. Perbankan konvensional dengan menerapkan bunga merupakan kedhaliman dan tidak adil karena telah mengeksploitasi nasabah sedangkan perbankan syariah dengan menerapkan berbagi keuntungan dan kerugian merupakan usaha yang adil. $\mathrm{Hal}$ itu berdasarkan teori kebijakan publik, bahwa hukum sebagai bagian dari materi kebijakan publik menurut Grindle bahwa keberhasilan implementasi kebijakan dipengaruhi oleh isi kebijakan. ${ }^{10}$ Hukum sebagai bagian dari kebijakan bahwa implementasinya atau penerapannya di lapangan itu dipengaruhi oleh isi materi hukum, sehingga bila isi materinya benar dan adil, maka pelaksanannya juga benar dan adil dan sebaliknya.

Kontradiksi ini akan membawa dampak ketidakpastian hukum di dunia perbankan. Masyarakat akan semakin bingung bahwa orang boleh berbuat ketidakadilan tetapi disatu sisi dilarang berbuat tidak adil. Maka pembangunan hukum perbankan di Indonesia mengalami kebingungan dalam hal menerapkan keadilan.

Padahal di dalam praktik perbankan konvensional telah mengalami kegagalan pada tahun 1998 dengan krisis moneter. Pada tahun 1998 Indonesia mengalami masalah besar dalam industri perbankan salah satunya disebabkan sistem perbankan konvensional yang tidak sehat, sehingga berdampak pada krisis ekonomi di Indonesia yang panjang, bahkan negara lain ekonominya sudah normal, di Indonesia masih terasa krisis ekonomi. Hal itu menunjukan bahwa bank konvensional berdasarkan bunga belum memberikan rasa keadilan dalam ekonomi di masyarakat dan tidak sesuai dengan Pancasila dan Undang-Undang Dasar (UUD) 1945.

Pengaruh dari dualisme undang-

10 M.S. Grindle, 1980, Politics And Policy Implementation In The Third Word, Princeton University Press, Princeton, hal.7 dalam Bambang Sunggono, Hukum dan Kebijakan Publik, Sinar Grafika, Jakarta, 1994, hal.148 undang yang kontradiksi tersebut, penerapan berbagi keuntungan dan kerugian berjalan setengah-setengah, tidak utuh dan tidak adil, bahkan cenderung bank syariah masih tetap menerapkan bunga seperti di bank konvensional, hanya saja ada perubahan pada nomenklatur atau bahasa. Pengaruh yang lainnya adanya dualisme undang-undang yang kontradiksi adalah tidak adanya kepastian hukum, karena masyarakat bingung, hukum mana yang memberikan keadilan, karena kedua-duanya diberlakukan di Indonesia.

\section{b) Faktor Struktur Hukum}

Maksud struktur hukum menurut teori Friedman adalah lembaga yang menjalankan hukum yaitu perbankan syariah. Lembaga perbankan syariah merupakan bagian sistem hukum yang menentukan pelaksanaan hukum. Dalam teori kebijakan, struktur sangat berpengaruh kepada pelaksanaan hukum, tidak hanya manusia saja yang berpengaruh terhadap jalannya hukum tetapi struktur juga berpengaruh terhadap jalannya hukum. ${ }^{11}$

Di Indonesia sekarang ini terdapat dua lembaga perbankan yang saling kontradiksi dalam praktik kegiatan usaha. Dual lembaga perbankan itu adalah perbankan konvensional dan perbankan syariah. perbankan konvensional berbasis bunga yang tidak adil dan Bank Syariah yang berbasis berbagi keuntungan dan kerugian yang adil menurut disertasi Mustaghfirin dan Dadan Muttaqien. ${ }^{12}$

Dua lembaga yang berbeda dalam praktik tersebut memberikan kesempatan kepada masyarakat yang senang dengan bunga berafiliasi kepada bank konvensional, padahal bank konvensional

11 Bambang Sunggono, 1994, Hukum dan Kebijakan Publik, Sinar Grafika, Jakarta, hal.146

12 Mustaghfirin, 2006, Rekonstruksi Sistem Hukum Perbankan di Indonesia Kajian dari Aspek Filososfis, Sosiologis dan Budaya, Unissula Press, Semarang, hal. 9-16. Dan Dadan Muttaqien, 2007, Sistem Perbankan Syariah di Indonesia dalam Perspektif Politik Hukum, Disertasi Universitas Diponegoro, Semarang, hal.361. 
yang berbasis bunga dinyatakan tidak memberikan keadilan dan itu melanggar Pancasila terutama sila pertama "ketuhanan yang maha esa" dan sila ke dua "kemanusiaan yang adil dan beradab" dan juga sila ke lima "keadilan sosial bagi seluruh rakyat Indonesia".

Sila pertama dari Pancasila mengatur bahwa lembaga apapun di Indonesia ini hendaknya sesuai dengan filosofi sila pertama yaitu ketuhanan yang maha esa, yang berarti bahwa keberadaan bank di Indonesia harus selaras dengan aturan agama di Indonesia dan bank konvensional berbasis bunga tidak ada satupun agama di Indonesia yang membolehkan bunga.

Namun di sisi lain masyarakat juga disuguhi bank syariah yang sesuai dengan Pancasila yaitu sila pertama "ketuhanan yang maha esa". Masyarakat merasa ada kebingungan dalam menerapkan aturan-aturan agama yang selaras dengan Pancasila. Itulah yang menjadi sumber utama sebagian praktisi perbankan syariah masih menjalankan usaha di bank syariah tetapi rasa bunga di bank konvensional.

Sila ke dua dan sila ke lima dari Pancasila mengatur bangsa Indonesia dari sisi nilai keadilan. Bangsa Indonesia menjunjung tinggi nilai keadilan yang buktinya ada di dalam pasal ke dua dan ke lima dari Pancasila. Artinya bahwa lembaga apapun yang berdiri di Indonesia termasuk kegiatannya supaya menegakkan nilai keadilan sebagaimana yang diamanatkan oleh Pancasila. Bank konvensional sebagai lembaga perbankan yang berbasis bunga tidak mungkin akan bisa melaksanakan amanat tersebut karena bunga bersifat mengeksploitasi nasabah baik nasabah investor maupun nasabah kredit. Nasabah investor biasanya ia akan mendapat bunga yang kecil bila menaruh dananya di bank konvensional sehingga bisa saja ia merugi dan nasabah kredit ia akan terkena bunga tinggi yang harus dibayar setiap bulan walaupun usahanya rugi pada waktu itu, sehingga terjadi eksploitasi yang kuat ekonominya kepada ekonomi lemah, maka di sinilah terjadi pelanggaran sila ke dua dan sila ke lima.

Bank konvensional yang berbasis bunga telah menjalankan kegiatan yang menurut Pancasila tidak adil namun faktanya bank konvensional masih di perbolehkan berdiri di Indonesia dan masih menjalankan usahanya dengan nyaman saja, hal itu lah yang menjadikan negara Indonesia belum konsisten menjalankan Pancasila secara utuh.

Nilai keadilan di Indonesia merupakan panglima dari pembangunan hukum di Indonesia, namun seakan-akan tak berdaya menghadapi bank konvensional sehingga keberadaannya dipertahankan di Indonesia sehingga mengaburkan tujuan bangsa Indonesia ini berbangsa dan bernegara.

Walupun demikian, Undang-Undang Perbankan baik konvensional maupun dalam Undang-Undang Perbankan Syariah ke dua-duanya mencantumkan nilai keadilan sebagai berikut:

"Undang-Undang Nomor 7 tahun 1992 jo. Undang-Undang Nomor 10 Tahun 1998 tentang perbankan yaitu "Bahwa pembangunan nasional yang dilaksanakan selama ini merupakan upaya pembangunan yang berkesinambungan dalam rangka mewujudkan masyarakat yang adil dan makmur berdasarkan Pancasila dan Undang-Undang Dasar 1945" begitu juga dalam penjelasan Undang-Undang Nomor 21 Tahun 2008 tentang Perbankan Syariah yang mengatakan bahwa "Tujuan pembangunan nasional adalah terciptanya masyarakat yang adil dan makmur". ${ }^{13}$

Amanat tersebut menginstruksikan bahwa secara keseluruhan isi ke dua undang-undang ini adalah untuk memberikan keadilan kepada semua

\footnotetext{
13 Himpunan Peraturan Perundang-undangan, 2008, Undang-Undang Perbankan Syariah dan Surat Berharga Syariah, Fokus Media, Bandung, hal.82
} 
pihak yang melakukan hubungan hukum dengan pihak perbankan. Hal itu menunjukkan adanya dua lembaga yang bertolak belakang namun dianggap ke dua-duanya adil sehingga membuat masyarakat Indonesia bingung dalam menentukan pilihan lembaga perbankan di Indonesia dan secara logika tidak mungkin ada dua lembaga yang bertolak belakang dalam prinsip dan nilai tetapi ke dua-duanya sama-sama adil, tentu yang adil hanya ada satu yaitu salah satu diantara keduanya yaitu perbankan syariah.

Bila melihat content dari ke dua perundang-undangan tentang bank yang ada di undang-undang bank konvensional dan undang-undang bank syariah akan semakin jelas adanya kontradiksi dalam hal pelaksanaan kegiatan perbankan dimana yang satu menjunjung tinggi keadilan di bank syariah dan yang satu lagi menjunjung nilai ketidakadilan yang diwakili dengan praktik bunga di bank konvensional sebagai berikut:

Undang-Undang Nomor 21 Tahun 2008 mengawali peraturan dengan pertimbangan landasan filosofi undangundang perbankan syariah yaitu ${ }^{14}$ sejalan dengan tujuan pembangunan nasional Indonesia untuk mencapai terciptanya masyarakat adil dan makmur berdasarkan demokrasi ekonomi, dikembangkan sistem ekonomi yang berlandaskan pada nilai keadilan, kebersamaan, pemerataan, dan kemanfaatan yang sesuai dengan prinsip syariah.

Pertimbangan landasan filosofi tersebut dijelaskan dalam ketentuan umum Undang-Undang Nomor 21 Tahun 2008 tentang perbankan syariah bahwa Pancasila dan Undang-Undang Dasar Negara Republik Indonesia Tahun 1945 telah mengamanatkan tujuan pembangunan nasional yaitu terciptanya masyarakat yang adil dan makmur berdasarkan demokrasi ekonomi,

14 Undang-Undang Nomor 21 Tahun 2008 Tentang Perbankan Syariah dengan mengembangkan sistem ekonomi yang bertumpu pada mekanisme pasar yang berkeadilan. Agar tercapai tujuan pembangunan nasional dan dapat berperan aktif dalam persaingan global yang sehat, diperlukan partisipasi dan kontribusi semua elemen masyarakat untuk menggali berbagai potensi yang ada di masyarakat. ${ }^{15}$

Salah satu bentuk penggalian potensi dan wujud kontribusi masyarakat dalam perekonomian nasional tersebut adalah pengembangan sistem ekonomi berdasarkan nilai Islam (Syariah) dengan mengangkat prinsip-prinsip syariah ke dalam sistem hukum nasional. ${ }^{16}$

Salah satu prinsip syariah adalah larangan riba dalam berbagai bentuknya, dan menggunakan sistem prinsip bagi hasil. Dengan prinsip bagi hasil, Bank Syariah dapat menciptakan iklim investasi yang sehat dan adil karena semua pihak dapat saling berbagi baik keuntungan maupun potensi risiko yang timbul sehingga akan menciptakan posisi yang berimbang antara bank dengan nasabahnya. ${ }^{17}$

Undang-Undang Nomor 21 tahun 2008 tentang perbankan syariah tersebut mengawali dasar filosofi praktik perbankan syariah adalah berbagi keuntungan dan keadilan melalui kalimat "dengan prinsip bagi hasil, Bank Syariah dapat menciptakan iklim investasi yang sehat dan adil karena semua pihak dapat saling berbagi baik keuntungan maupun potensi risiko yang timbul" sehingga dalam pembiayaan murabahah juga dituntut untuk dapat berbagi keuntungan dan kerugian. Begitu sebaliknya tidak boleh ada keuntungan di satu pihak saja dan kerugian di satu pihak, kedua-duanya

15 Ibid Pasal 1

16 Undang-Undang Nomor 21 Tahun 2008 Tentang Perbankan Syariah Pasal 1

17 Tim Redaksi Fokus Media, 2008, Himpunan Peraturan Perundang-Undangan Tentang UndangUndang Perbankan Syariah dan Surat Berharga Syariah Negara, Penerbit Fokus Media, Bandung, hal.83 
harus dapat menerima keuntungan maupun kerugian.

Pelaksanaan atas filosofi undangundang tersebut, diaturlah murabahah melalui pasal 19 ayat 1 huruf (d) yaitu kegiatan usaha Bank Umum Syariah meliputi: menyalurkan pembiayaan berdasarkan akad murabahah, akad salam, akad istishna', atau akad lain yang tidak bertentangan dengan prinsip syariah. ${ }^{18}$

Sedangkan undang-undang perbankan konvensional mengatur kegiatan usahanya berbasis bung yang tidak adil sebagai berikut:

Bank konvensional tidak adil dalam menyalurkan kredit, karena berdasarkan bunga. Dasar bank konvensional menyalurkan kredit adalah UndangUndang Nomor 7 Tahun 1992 tentang Perbankan sebagaimana diubah menjadi Undang-Undang Nomor 10 Tahun 1998 tentang Perbankan. Bahwa Pasal 1 menyebutkan kredit adalah: ${ }^{19}$ Penyediaan uang atau tagihan yang dapat dipersamakan dengan itu, berdasarkan persetujuan atau kesepakatan pinjammeminjam antara bank dengan pihak lain yang mewajibkan pihak peminjam untuk melunasi hutangnya setelah jangka waktu tertentu dengan pemberian bunga.

Pasal tersebut yang menunjuk langsung adanya ketidakadilan adalah kalimat "pemberian bunga yang disebabkan transaksi pinjam meminjam". Dalam Islam pinjam-meminjam tidak boleh ada tambahan dalam pengembalian pokoknya, dan bila ada tambahan itu namanya riba, sedangkan Islam melarang keras untuk melakukan usaha yang mengandung riba.

Keadilan menurut Islam adalah menempatkan sesuatu pada tempatnya ${ }^{20}$

18 UU Nomor 21 Tahun 2008 Tentang Perbankan Syariah

19 C.S.T. Kansil dan Christine S.T. Kansil, 1999, Kitab Undang-Undang Hukum Perusahaan Jilid 1, Undang-Undang Nomor 10 Tahun 1998 Tentang Perbankan, Penerbit PT. Pradnya Paramita, Jakarta, hal.578

20 Abdul Aziz Dahlan (et.al) , 1996, Ensiklopedia Hukum Islam, Ichtiar Baru Van Hoeve, Jakarta, hal.25. atau memberikan hak seseorang secara seimbang seperti timbangan, ${ }^{21}$ maka keadilan substansial dalam pembiayaan di bank syariah adalah berbagi keuntungan dan kerugian sesuai dengan hak yang dimiliki oleh masing-masing pihak. Sedangkan keadilan formal adalah keadilan yang diterapkan hanya melihat dari sisi formalitas dan tidak melihat dari sisi adil berbagi keuntungan dan kerugian.

Bank syariah dalam melaksanakan pembiayaan murabahah hanya sebatas memenuhi formalitas sebagai pembiayaan atau sebagai pihak yang memberikan dana dan belum menerapkan keadilan substansial berbagi keuntungan dan kerugian, hal itu ditemukan dalam data sebagai berikut:

a) Pada saat nasabah mengajukan pembiayaan, bank syariah tidak menjelaskan secara detail tentang pembiayaan murabahah yang berakibat adanya utang piutang yang ada di dalam perjanjian:

b) Pada saat realisasi pembiayaan murabahah nasabah tidak dijelaskan secara rinci risikorisiko yang harus ditanggung oleh nasabah dalam kaitannya dengan pembiayaan murabahah ini, namun tiba-tiba sudah ada dalam perjanjian bahwa nasabah harus menanggung beberapa risiko antara lain : barang harus dicari oleh nasabah, dibeli sendiri oleh nasabah bahkan sampai pada peralihan barang semua ada pada tanggungjawab nasabah, Bank Syariah tidak memikul tanggung jawab risiko sedikitpun. Pada saat realisasi nasabah juga tidak ada kesempatan untuk bernegosiasi tentang harga, padahal salah satu unsur yang paling substansi dalam akad pembiayaan murabahah ini adalah jual beli, dan di dalam

21 Muhammad Taufiq, 2014, Keadilan Substansial Memangkas Rantai Birokrasi Hukum, Pustaka Pelajar, Yogyakarta, hal.57 
jual beli pasti ada negosiasi.

Dalam wawancara nasabah mengatakan: "saya mau apa lagi....margin sudah ditentukan, nasabah tidak bisa nego". 22

c) Bank syariah sebagai pemilik dana memberikan tekanan kepada nasabah pembiayaan murabahah untuk menanggung kerugian baik kehilangan dan rusak di jalan. Perjanjian tentang akad pembiayaan murabahah yang menjadi jaminan adalah barang yang dibeli oleh nasabah kemudian Bank Syariah minta supaya mengasuransikan barang tersebut. Hal itu diatur dalam perjanjian murabahah nomor: 2006.244. Isi perjanjian tersebut menunjukkan bahwa belum terpenuhinya keadilan substansial dan baru terpenuhi keadilan formalitas, karena apa yang menjadi kehendak bank syariah diatur di dalam perjanjian walaupun belum tentu nasabah menerima secara suka rela. Andaikan bisa bank syariah menerapkan berbagi keuntungan dan kerugian, maka ia memilih yang menerapkan berbagi keuntungan dan kerugian, maka nasabah mau menerima formalitas yang diperjanjikan oleh bank syariah, karena unsur keterpaksaan.

d) Diantarafaktoryangmenyebabkan berbagi keuntungan dan kerugian dalam pembiayaan murabahah di bank syariah tidak berjalan adil adalah niat yang salah tujuan dalam pengelolaan bank syariah yaitu menghindari riba dan bukan menghilangkan riba. Pengelolaan usaha di bank syariah tujuannya adalah menghilangkan riba dan bukan menghindari riba. Ada

22 Wawancara kepada nasabah Mubarok tanggal 5 Agustus 2016. perbedaan antara menghindari riba dengan menghilangkan riba. Bahwa menghindari riba akan memaksakan usaha bank syariah sebisa mungkin dan dengan model apapun yang penting seakan-akan tidak riba, padahal substansinya riba atau disebut upaya mensiasati akad supaya terhindar dari riba. Menghilangkan riba itu sudah ada niat kuat untuk tidak melaksanakan usaha bank syariah bila tidak benar-benar sesuai syariah. Melalui upaya melaksanakan syariah, maka bank syariah akan mencari formula produk yang benarbenar lurus sesuai syariah dan tidak hanya mensiasati akad supaya terhindar dari riba. Sebagian pakar Bank Syariah memberikan makna bunga sama dengan riba yaitu memberikan pinjaman uang atau kredit di bank konvensional dengan perjanjian adanya tambahan pengembalian di muka. ${ }^{23}$ Adanya tambahan pengembalian yang diperjanjikan di muka itulah yang dianggap riba menurut sebagian ahli perbankan syariah diantaranya Adiwarman A. Karim, sehingga tidak melihat substansi dari riba yaitu ketidakadilan dalam praktik pembiayaan.

e) Diantarafaktoryangmenyebabkan berbagi keuntungan dan kerugian dalam pembiayaan murabahah di bank syariah tidak berjalan adil adalah bank syariah menghindari berbagi keuntungan dan kerugian atau bank syariah hanya mau keuntungan saja.

Bank syariah dalam usahanya punya pandangan bahwa usaha itu harus untung dan tidak boleh merugi agar supaya dipercaya

23 Adiwarman A. Karim, 2010, Bank Islam Analisis Fiqih dan Keuangan, PT. Raja Grafindo Persada, Jakarta, hal.38 
oleh masyarakat investor. Niat tersebut merupakan komitmen yang bagus dan benar, tetapi tidak sepenuhnya benar, karena dalam usaha bisnis tidak akan selalu untung dan kadang kala ada juga ruginya, itulah sunnatullah. Rumus dalam usaha itu menurut ilmu matematika adalah tambah dan kurang atau dalam simbul (+ dan - ), bila usaha itu untung maka dikatakan tambah (+), tetapi bila usaha itu rugi maka dikatakan kurang (-). Kedua simbul dalam matematika itu selalu berpasangan yaitu dalam tambah dan kurang atau (+ dan -) dan dalam usaha akan selalu ada untung dan rugi, maka usaha perbankan syariah pasti juga ada untung dan rugi. Oleh karena itu yang paling penting dalam usaha perbankan syariah itu adalah berusaha secara akuntabilitas dapat dipertanggungjawabkan bahwa bank akan dapat keuntungan, dan bila kenyataannya adalah merugi, maka itu merupakan bagian dari tanggungjawab yang harus dipikul sebagai konsekuensi dari bank syariah mengambil keuntungan dalam usaha.

f) Kerugian dalam usaha menurut Islam merupakan suatu tanggungjawab yang harus dipikul oleh pengusaha dikarenakan ia mengambil keuntungan. Bila bank syariah tidak mau tanggungjawab terhadap kerugian, maka bank tidak boleh mengambil keuntungan dalam usaha. Pengambilan keuntungan lahyang menyebabkan bank syariah wajib menanggung kerugian bila ada.

g) Diantarafaktoryangmenyebabkan berbagi keuntungan dan kerugian dalam pembiayaan murabahah di bank syariah tidak berjalan adil adalah bank syariah menerapkan pembiayaan yang pragmatis. Pada saat dialog seminar tentang perbankan syariah di Universitas Islam Negeri Sunan Kalijaga muncul suatu pertanyaan mengapa bank syariah itu dalam pembiayaan marginnya lebih tinggi dibanding dengan bunga dalam bank konvensional? Kemudian pemateri dari perbankan syariah yaitu salah satu manajer di bank syariah menja bahwa bank syariah itu untuk transaksi satu membutuhkan berlembarlembar kertas, sementara di bank konvensional satu transaksi bisa satu kertas, sehingga di bank syariah itu belum bisa efisien dan praktis, sementara di bank konvensional itu praktis" 24 . Jawaban tersebut tidak bisa menjadi alasan bahwa margin di bank syariah itu tinggi dibanding dengan bunga di bank konvensional. Melihat harga kertas yang begitu murah dibanding dengan keuntungan di bank syariah sungguh tidak sebanding, karena keuntungan masih lebih tinggi dibandingkan dengan biaya membeli kertas yang hanya sedikit saja..

h) Diantarafaktoryangmenyebabkan berbagi keuntungan dan kerugian dalam pembiayaan murabahah di bank syariah tidak berjalan adil adalah persaingan antara bank syariah dan bank konvensional dalam pembiayaan. ${ }^{25}$ Persaingan di dalam dunia usaha atau bisnis merupakan hal yang wajar dan sudah terbiasa, namun yang dikehendaki adalah persaingan yang sehat dan tidak ada atauran

24 Wawancara dengan salah satu Direktur Bank Syariah Mandiri saat mengikuti Indonesian Islamic University Conference (IIUC) 26 Januari 2017

25 Ascarya, 2007, Akad \& Produk Bank Syariah, Raja Grafindo Persada, Jakarta, hal.132 
syariah yang dilanggar. Menurut Islam persiangan itu juga merupakan anjuran dalam Islam yaitu fastabiqul khairat (berlombalombalah dalam kebaikan). Bank syariah merasa bahwa bank konvensionala sebagai bank yang sudah berdiri lama dan mempunyai permodalan yang kokoh dan nasabahnya sudah banyak, sedangkan bank syariah merasa sebagai bank yang menjadi pendatang baru yang kurang kuat modal dan sedikit nasabahnya, maka tidak mungkin bank syariah tidak mengikuti caracara bank konvensional dalam hal pembiayaan. Misalnya di bank konvensional ada kredit berbasis bunga, maka bank syariah mengadopsi kredit dengan modifikasi melalui pembiayaan murabahah yaitu jual beli dengan menyebut harga pokok ditambah margin keuntungan. Sehingga praktik murabahah disamakan dengan kredit hanya disiasati dengan praktik jual beli sehingga tidak tampak adanya bunga dalam pengembalian pembiayaan.

\section{c) Faktor Budaya Hukum}

Budaya hukum di masyarakat menurut teori sosiologi hukum sangat tergantung kepada empat hal yaitu: pengetahuan hukum, penghayatan hukum, penerapan hukum dan ketaatan hukum. ${ }^{26}$

Seseorang akan menjalankan hukum dengan baik bila ia mengetahui hukum, maka pengetahuan hukum menjadi syarat seseorang dapat menjalankan hukum dengan baik. Dengan berbagai macam seseorang mendapatkan pengetahuan hukum, bisa melalui membaca undangundang baik cetak maupun elektronik. Hasil bacaan terhadap undang-undang pun hasilnya bisa berbeda-beda dan juga akan menghasilkan pemahaman hukum yang berbeda-beda dan juga akan mempengaruhi seseorang melaksanakan hukum. Menurut teori kebijakan publik syarat untuk mendapatkan pengetahuan hukum yang baik, diperlukan sarana dan prasarana yang memadahi, sehingga orang mudah mendapatkan informasi tentang hukum.

Dalam Islam orang bisa terbebas dari hukum bila ia dalam kondisi tiga hal yaitu kondisi tidur sampai ia bangun, kondisi gila sampai ia sadar dan dalam kondisi masih kecil sampai ia baligh atau cakap hukum. Dalam kondisi tersebut seseorang tidak mungkin untuk melaksanakan hukum dengan baik, sehingga ia terbebas dari hukum.

Sedangkan di Indonesia berlaku suatu azas bahwa semua orang dianggap tahu hukum, sehingga dia wajib melaksanakan hukum dengan baik. Azas ini sering menjadi masalah bagi masyarakat bahwa ia dianggap tahu hukum walaupun kenyataannya tidak tahu, maka apakah orang yang tidak megetahui hukum dapat dijatuhi hukuman?

Masalah tersebut telah dijawablah oleh Al-Qur'an bahwa "Allah tidak akan memberi hukuman pada seseorang sebelum diutusnya Rasul (Q.S. Al-Isra': 15)". Ayat tersebut memberikan satu azas hukum yaitu seseorang tidaklah dapat dihukum sebelum ada Rasul yang memberipengetahuantentang hukum. ${ }^{27}$

Tidak mengetahui hukum dapat diartikan bahwa orang tersebut tidak mengetahui bahwa perbuataan yang dilakukannya adalah perbuatan melanggar hukum atau dapat diartikan bahwa orang tersebut memang tidak mengetahui bahwa norma hukum yang mengatur tentang sesuatu perbuatan yang dilanggarnya, memang sudah diatur. Jadi kata-kata yang sering kita lihat, "dianggap telah mengetahui" itu tidak berlaku bagi alQur'an.

26 OK. Chairuddin, 1991, Sosiologi Hukum, Sinar Grafika, Jakarta, hal.102

27 Al-Qur'an Surah Q.S.17:15 
Penghapusan kata "dianggap telah mengetahui" maka setiap orang wajib pula untuk saling memberitahukan agar ada saling mengontrol antara satu dengan lainnya. Misalnya : Barang siapa yang telah mengetahui tentang isi dari sesuatu peraturan (hukum) diwajibkan untuk menyebarluaskannya, dengan demikian semua orang jadi bertanggung jawab atas pelaksanaannya.

Hal ini tidak aneh dalam hukum Islam karena telah diatur di dalam AlQur'an, orang untuk mau taat hukum ia harus terlebih dahulu mengetahui dan menghayati hukum, hukum yang disusun tanpa memperhatikan aspek ini, justru akan menimbulkan kesulitan dalam penerapannya, karena orang yang mengetahui tentang sesuatu akan lebih mudah untuk memahami, kemudian menimbulkan keinginan untuk menghayati dan mematuhinya, dibanding orang yang tidak mengetahui hukum.

Jika dalam suatu masyarakat masingmasing individu telah mengetahui hukum, maka terciptalah dalam masyarakat itu perasaan kolektif untuk menghormati dan mentaati hukum, untuk itu dalam penyusunan kaidah hukum perlu memperhatikan kenyataan yang ada dalam masyarakat. Artinya penyusunan kaidah hukum itu harus sesuai dengan realitas sosial, agar hukum yang dibentuk itu harus mencerminkan aspirasi masyarakat. Jadi ia tidak hanya dijadikan sebagai alat untuk melegalisir tindakantindakan tertentu, yang sampai pada tingkat terakhir hukum itu sebagai alat atau simbol untuk membenarkan suatu tindakan.

Asas hukum yang ditentukan oleh Islam bahwa seseorang tidak bisa dihukumi hingga diutusnya Rasul yang memberi tahu hukum, dalam kontek Indonesia hal itu sudah terpenuhi dengan adanya menteri hukum dan perundangundangan yang menjelaskan tentang hukum, sehingga pelaksanaan hukum yang ada di Indonesia sudah sejalan dengan hukum Islam dan dalih adanya hambatan bahwa masyarakat muslim yang berpedoman pada al-Qur'an tersebut gugur dengan adanya menteri hukum dan perundang-undangan. Yang perpenting dalam pemaham hukum adalah adanya sosialisasi hukum dari pihak pemerintah ataupun teknis yang ditunjuk oleh pemerintah untuk menanganinya.

Pengetahan hukum yang baik, akan berpengaruh pada penghayatan hukum yang baik juga. Melalui penghayatan hukum akan mengetahui kemana arah tujuan hukum itu. Bacaan yang mendalam terhadap hukum akan melahirkan penghayatan yang mendalam terhadap hukum, sehingga ia akan mampu melaksanakan hukum dengan baik.

Penghayatan terhadap hukum Islam adalah merupakan dasar bagi seseorang untuk dapat menghayati hukum. Dengan mengetahui hukum, seseorang akan menghayati berbagai tujuan hukum yang dibuat. Juga akan tahu batasan-batasan didalam penggunaan hukum sebagai sarana untuk mengatur perikelakuan warga-warga masyarakat. Sebab, sarana yang ada membatasi tujuan, sedangkan tujuan menentukan sarana-sarana apakah yang tepat untuk dipergunakan.

\section{Kesimpulan dan saran}

Berdasarkan rumusan masalah penerapan hukum tentang berbagi keuntungan dan keruigan dalam pembiayaan murabahah di Bank Syariah Indonesia dapat disimpulkan sebagai berikut:

a) Penerapan hukum tentang berbagi keuntungan dan kerugian dalam pembiayaan murabahah di Bank Syariah Indonesia berdasarkan keadilan perspektif Hukum Islam adalah pembiayaan murabahah di Bank Syariah Indonesia tidak menerapkan hukum berbagi keuntungan dan kerugian secara adil berdasarkan nilai-nilai dalam hukum Islam bahwa pengambilan keuntungan harus didasarkan pada tiga kriteria yaitu adanya usaha, adanya berbagi tanggung jawab, dan adanya berbagi risiko. Bank 
Syariah dalam menerapkan pembiayaan murabahah tidak memenuhi kriteria tersebut dalam mengambil keuntungan. Bank Syariah melaksanakan produk pembiayaan murabahah dengan langkah nasabah diminta mewakili Bank Syariah untuk mencari barang sendiri yang dibutuhkan, sekaligus bertanggungjawab terhadap semua risiko yang ditimbulkan, kemudian setelah mendapatkan barang berupa rumah atau mobil dianggap barang itu milik Bank Syariah, kemudian dijual kepada nasabah dengan harga pokok ditambah margin keuntungan dan nasabah menanggung semua biaya mulai administrasi, asuransi, biaya pengikatan jaminan dan biaya materai. Keuntungan ditentukan oleh pihak Bank Syariah dan nasabah hanya disuguhkan perjanjian yang isinya hutang piutang dengan nasabah membayar secara mengangsur setiap bulan. Model angsuran yang diterapkan oleh Bank Syariah adalah sama dengan bank konvensional yaitu bunga menurun. Berdasarkan penerapan pembiayaan murabahah tersebut, Bank Syariah faktanya tidak menerapkan berbagi keuntungan dan kerugian secara adil karena tidak ada usaha, tidak ada tanggung jawab dan tidak ada berbagi resiko.

b) Penerapan hukum tentang berbagi keuntungan dan kerugian dalam pembiayaan murabahah di Bank Syariah Indonesia belum memberikan keadilan faktornya adalah tiga hal yaitu kelemahan dari sisi substansi hukum, struktur hukum dan kultur hukum. Kelemahan dari sisi substansi hukum yaitu adanya dua regulasi perbankan yang kontradiksi $100 \%$ yaitu undang-undang tentang perbankan konvensional berbasis bunga yang tidak adil dan undang-undang tentang perbankan syariah berbasis berbagi keuntungan dan kerugian yang adil, undang-undang tentang perbankan syariah mengatur tentang berbagi keuntungan dan kerugian dalam filosofinya di pasal 1 dan belum mengaturnya di dalam pasal-pasal yang lebih rinci, dan kegiatan usaha Bank Syariah hanya diatur melalui fatwa Majelis Ulama Indonesia yaitu fatwa Dewan Syariah Nasional dan juga dalam peraturan Bank Indonesia yang keduanya belum menjadi peraturan dalam hierarkhi perundang-undangan sehingga kedudukannya kurang kuat daya paksanya. Kelemahan yang ada di dalam struktur hukum meliputi : adanya dualisme lembaga perbankan yang kontradiksi 100\%, faktor Bank Syariah yang terjebak dalam penerapan keadilan formal dan tidak menerapkan keadilan substansial, faktor Bank Syariah yang masih berparadigma kapitalis dan belum berparadigma Islami, faktor pengelola Bank Syariah yang salah tujuan pengelolaan Bank Syariah yaitu menghindari riba dan bukan menghilangkan riba, faktor Bank Syariah yang maunya hanya keuntungan dan tidak mau merugi, faktor Bank Syariah yang mempertahankan penerapan hukum tentang pembiayaan murabahah yang pragmatis, faktor persaingan antara Bank Syariah dan bank konvensional, faktor kebijakan komisaris atau pemilik saham yang tidak sesuai syariah atau tidak mau rugi dan faktor dewan pengawas syariah yang lemah dalam pengawasan kepada Bank Syariah. Lemahnya budaya atau kultur hukum meliputi : faktor lemahnya pemahaman sebagian pakar perbankan syariah tentang riba, faktor nasabah atau masyarakat yang sebagian berparadigma pragmatisme kapitalisme, faktor lemahnya pemahaman masyarakat terhadap produk Bank Syariah, dan faktor nilai mata uang yang selalu inflasi dan belum dijamin dengan emas yang stabil.

Para praktisi perbankan syariah seharusnya melaksanakan nilai-nilai Hukum Islam yang adil berbagi keuntungan dan kerugian dalam pembiayaan murabahah yang terbebas dari riba. Pembiayaan murabahah yang dipraktikkan sekarang ini tidak adil dan dapat diganti dengan menerapkan mudharabah wa al-murabahah, musyarakah wa al-murabahah dan musyarakah wa ijarah al-muntahia bit-tamlik. 


\section{Daftar Pustaka}

\section{Al-Qur'an}

Abul A'la al-Maududi, Riba, 1970, Terjemahan Abdullah Suhaili, Penerbit Hudaya, Jakarta

Abdul Aziz Dahlan (et.al) , 1996, Ensiklopedia Hukum Islam, Ichtiar Baru Van Hoeve, Jakarta Ascarya, 2007, Akad \& Produk Bank Syariah, Raja Grafindo Persada, Jakarta

Adiwarman A. Karim, 2010, Bank Islam Analisis Fiqih dan Keuangan, PT. Raja Grafindo Persada, Jakarta,

C.S.T. Kansil dan Christine S.T. Kansil, 1999, Kitab Undang-Undang Hukum Perusahaan Jilid 1, Undang-Undang Nomor 10 Tahun 1998 Tentang Perbankan, Penerbit PT. Pradnya Paramita, Jakarta

Dadan Muttaqien, 2007, Sistem Perbankan Syariah di Indonesia dalam PerspektifPolitik Hukum, Disertasi Universitas Diponegoro, Semarang

Frank E. Vogel dan Samuel L. Hayes, 1998, Islamic Law And Finance: Religion, Risk, And Return, Kluwer Law International, Cambridge, Massachusetts.

Muhammad Abdul Mannan, 1995, Islamic Economics, Theory and Practice, terjemahan M. Nastangin, Teori dan Praktik Ekonomi Islam, Penerbit Dana Bhakti Wakaf, Yogyakarta

Muhammad Taufiq, 2014, Keadilan Substansial Memangkas Rantai Birokrasi Hukum, Pustaka Pelajar, Yogyakarta

Mustaghfirin, 2006, Rekonstruksi Sistem Hukum Perbankan di Indonesia Kajian dari Aspek Filososfis, Sosiologis dan Budaya, Unissula Press, Semarang

OK. Chairuddin,1991, Sosiologi Hukum, Sinar Grafika, Jakarta

Sobirin Asnawi, Siwi Purwandari dan Waluyati Handayani, 2007, Hukum Keuangan Islam: Konsep, Teori dan Praktik, Penerbit Nusamedia, Bandung

Tim Redaksi Fokus Media, 2008, Himpunan Peraturan Perundang-Undangan Tentang UndangUndang Perbankan Syariah dan Surat Berharga Syariah Negara, Penerbit Fokus Media, Bandung

UU Nomor 21 Tahun 2008 Tentang Perbankan Syariah 